\title{
Synthesis of natural maleimides farinomaleins C-E and evaluation of their antifungal activity
}

Santosh Lahore ${ }^{\mathrm{a}}$, Sachin T. Aiwale ${ }^{\mathrm{a}}$, Paola Sardi ${ }^{\mathrm{b}}$, Sabrina Dallavalle $\mathrm{a}^{\mathrm{F}^{*}}$

${ }^{\mathrm{a} D e p a r t m e n t}$ of Food, Environmental and Nutritional Sciences, Division of Chemistry and Molecular Biology, Università di Milano, Via Celoria 2, 20133 Milano, Italy.

${ }^{\mathrm{b}}$ Department of Food, Environmental and Nutritional Sciences, Division of Agro-Environmental Sciences, Università di Milano, Via Celoria 2, 20133 Milano, Italy.

\begin{abstract}
A practical and convenient synthesis of naturally occurring farinomaleins C-E was achieved starting from readily available ethyl 3-methyl-2-oxobutyrate and triethyl phosphonoacetate. The key steps of the sequence included a Horner-Wadsworth-Emmons condensation to obtain the precursor farinomalein A and coupling with suitable alcohols to install the chain. The synthesis of farinomalein $\mathrm{D}$ has been achieved starting from $(R)$-isopropylideneglycerol on the basis of which the $S$ configuration was assigned to the natural compound. The antifungal activity of the synthesized compounds was evaluated against Cladosporium cladosporioides.
\end{abstract}

Keywords: farinomaleins, maleimides, antifungal activity, synthesis, natural products.

As part of our studies on the synthesis of natural compounds endowed with antifungal activity, we have recently focused our attention on farinomalein A, a simple maleimide isolated in 2009 from the entomopathogenic fungus Paecilomyces farinosus by Putri et.al. ${ }^{1}$ The compound showed potent inhibition of Phytophtora sojae, a plant pathogen that every year causes enormous damage to soybean crops. Recently, El Amrani et al. ${ }^{2}$ have isolated three new farinomalein derivatives, farinomaleins $\mathrm{C}-\mathrm{E}$, from an unidentified endophytic fungus of the mangrove plant Avicennia marina from Oman. We describe herein a short and convenient synthesis of these new compounds, which are naturally occurring esters of farinomalein A (Figure 1).

* Corresponding author Tel. +39 250316818 Fax +39 250316801 E-mail address: sabrina.dallavalle@unimi.it 
<smiles>CC(C)C1=CC(=O)N(CCC(=O)O)C1=O</smiles>

Farinomalein A (1) $\mathrm{R}=\mathrm{H}$ Farinomalein $\mathrm{C}(2) \mathrm{R}=\mathrm{C}_{4} \mathrm{H}_{9}$<smiles>CC(C)C1=CC(=O)N(CCC(=O)OCC(O)CO)C1=O</smiles>

Farinomalein $D(3)$<smiles>C/C(=C\C(=O)O)CCOC(=O)CCN1C(=O)C=C(C(C)C)C1=O</smiles>

Figure 1. Structures of farinomaleins.

The first synthetic approach to farinomalein A was reported by Miles and Yan. ${ }^{3}$ The sequence is based on the reaction of isovaleraldehyde and glyoxylic acid to give a $\gamma$-hydroxybutenolide. Successive oxidation to the corresponding anhydride and treatment with $\beta$-alanine affords farinomalein A. However, the Authors themselves state that their synthesis is difficult to scaleup, ${ }^{3}$ due to the use of the hazardous and expensive oxidant Dess-Martin periodinane. More recently, an alternative strategy for the preparation of farinomalein A has been reported by us. ${ }^{4}$ The synthesis has been developed in four steps with high yield and without using any hazardous chemical (Scheme 1).

We envisioned that farinomaleins C-E could be synthesized by simply coupling farinomalein A, obtained from the previously reported procedure, with suitable alcohols. Thus, farinomalein $\mathrm{C}$ was obtained in $92 \%$ yield by reacting farinomalein A with 1-butanol using DCC and DMAP in DCM (Scheme 1$)^{5}$. 
<smiles>CCOC(=O)C(=O)C(C)C</smiles><smiles>CCOC(=O)CP(=O)(O)OCC</smiles>

$\underset{50^{\circ} \mathrm{C}, 1 \mathrm{~h}, 80 \%}{\stackrel{\mathrm{NaH}, \mathrm{THF}, 0^{\circ} \mathrm{C}-}{\longrightarrow}}$<smiles>CC(C)C1=CC(=O)N(CCC(=O)O)C1=O</smiles>

$\underset{\text { DCM, rt, overnight, } 92 \%}{\stackrel{\text {-butanol, DCC, DMAP }}{\longrightarrow}}$

$\mathrm{AcOH}$, reflux, $1.5 \mathrm{~h}, 60 \%$<smiles>CCOC(=O)C=C(C(=O)OCC)C(C)C</smiles>

a) $\mathrm{LiOH}, \mathrm{THF}, \mathrm{rt}$, $8 \mathrm{~h}, 96 \%$

b) TFAA, quant<smiles></smiles><smiles>CCOC(=O)CCN1C(=O)C=C(C(C)C)C1=O</smiles>

2 (Farinomalein C)

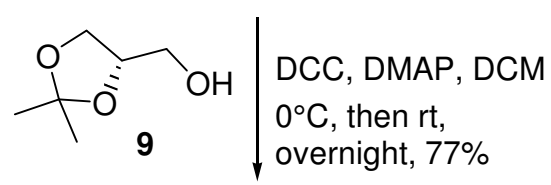<smiles>CC(C)C1=CC(=O)N(CCC(=O)OCC2COC(C)(C)O2)C1=O</smiles>

$\mathrm{AcOH} / \mathrm{H}_{2} \mathrm{O}$ $50^{\circ} \mathrm{C}, 3 \mathrm{~h}, 70 \%$<smiles>CC(C)C1=CC(=O)N(CCC(=O)OC[C@H](O)CO)C1=O</smiles>

10

$(R)$-3 (R) - Farinomalein D

Scheme 1. Synthesis of farinomaleins A, C and D.

Similarly, the synthesis of farinomalein D was carried out. As the absolute configuration at C-2' was not assigned by the Authors, we decided to synthesize both the enantiomers along with racemic farinomalein $\mathrm{D}$. Scheme 1 summarizes the synthesis of $(R)$-farinomalein $\mathrm{D}((R)-3)$ from (S)-9. After coupling with farinomalein A using DCC and DMAP, ${ }^{6}$ deprotection of $\mathbf{1 0}$ was first attempted by using $\mathrm{SmCl}_{2}$ in ethanol at reflux. This method allowed to obtain the desired compound in high yield but with complete racemization. Therefore, removal of the protecting group was carried out in $\mathrm{AcOH} / \mathrm{H}_{2} \mathrm{O}\left(4: 1\right.$, v/v) maintaining the temperature at $50{ }^{\circ} \mathrm{C}$ for $3 \mathrm{~h}$, as reported by Mori. ${ }^{7}(R)$-Farinomalein $\mathrm{D},{ }^{8}$ obtained in $70 \%$ yield, showed optical rotation opposite to that reported for the natural compound $\left([\alpha]_{\mathrm{D}}{ }^{25}-7.2(\mathrm{c} 1.0, \mathrm{MeOH})\right.$, lit. ${ }^{4}:[\alpha]_{\mathrm{D}}{ }^{25}+7.9$ (c $0.03, \mathrm{MeOH})$ ).

The same reaction pathway was followed to prepare $(S)$-farinomalein D $(S)$-3 starting from $(R)-\mathbf{9}$ in $58 \%$ overall yield $\left([\alpha]_{\mathrm{D}}{ }^{25}+7.3(\mathrm{c} 1.0, \mathrm{MeOH})\right)$. Racemic farinomalein $\mathrm{D}$ was also prepared for structure-activity relationship studies, starting from DL-1,2-isopropylideneglycerol.

As $(S)$-farinomalein D showed the same sign of specific rotation reported for the natural compound, we may safely deduce that the absolute configuration of natural farinomalein $\mathrm{D}$ is $S$. 
After several attempts, an optimized reaction sequence for the synthesis of farinomalein $\mathrm{E}$ was developed (Scheme 2). The carbonyl group of $\beta$-keto ester 11 was protected using standard methodology providing ketal 12. ${ }^{9}$ Reduction of $\mathbf{1 2}$ with lithium aluminium hydride gave the primary alcohol $\mathbf{1 3}$ in $91 \%$ yield. In the key transformation, treatment of $\beta$-hydroxy ketal $\mathbf{1 3}$ with oxalic acid and wet silica gel according to the procedure by Hitchcock ${ }^{10}$ provided the $\beta$ hydroxyketone $\mathbf{1 4}$ in high yield without elimination products. Compound $\mathbf{1 4}$ was protected as tetrahydropyranyl derivative $(\mathbf{1 5})^{11}$ and this latter was condensed with methyl (triphenylphosphoranylidene) acetate via benzoic acid catalyzed Wittig reaction. ${ }^{12}$ A 3:2 mixture of $Z$ and $E \alpha, \beta$-unsaturated esters 16 and 17 was produced. The mixture was treated with methanolic $\mathrm{HCl}$ without separation of the stereoisomers. Following removal of the THP group, the $Z$ isomer $\mathbf{1 6}$ underwent spontaneous lactonization to $\mathbf{1 8}$ and could thus be removed in a facile chromatographic separation from the desired hydroxyester 19 (43\% yield after purification). Finally, saponification with sodium hydroxide in water, followed by acidification, gave the acid $\mathbf{2 0}$ in quantitative yield. Farinomalein E was then obtained by coupling of $\mathbf{2 0}$ with farinomalein A in $42 \%$ yield. ${ }^{13}$

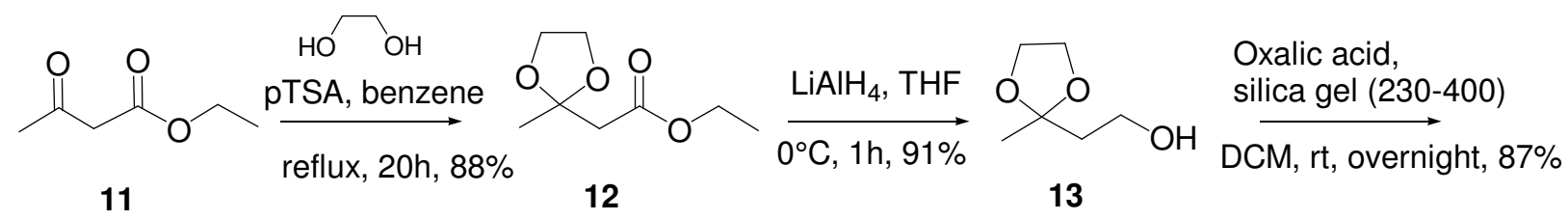

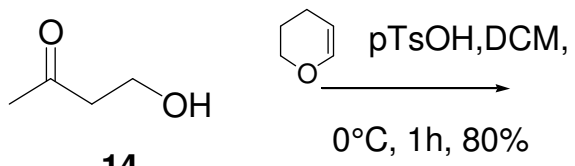

14<smiles>CC(=O)CCOC1CCCCO1</smiles>

15
$\mathrm{Ph}_{3} \mathrm{P}=\mathrm{CHCO}_{2} \mathrm{Me}$
toluene, 3 days, $42 \%$

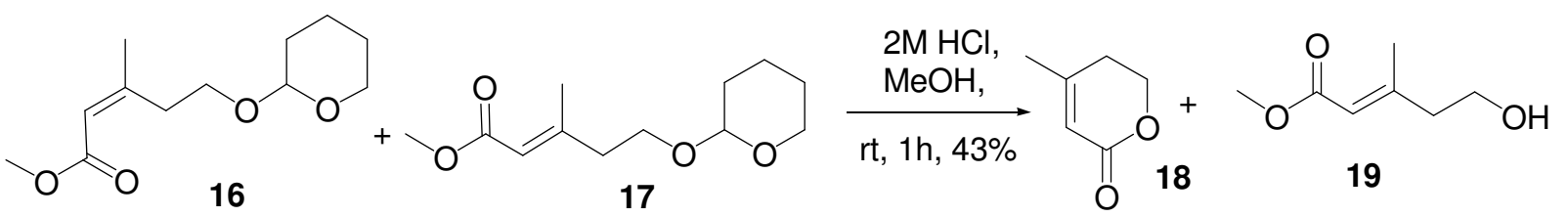
17<smiles>CC(=CC(=O)O)CCOC(=O)CCN1C(=O)C=C(C(C)C)C1=O</smiles>

Scheme 2. Synthesis of farinomalein E. 
The antifungal activity of the synthesized natural compounds (farinomaleins A, C-E) was investigated on Cladosporium cladosporioides using the method of bioautography. ${ }^{14,15}$

The results confirmed that farinomalein $\mathrm{A}$ is endowed with antifungal activity on this pathogen, the minimum amount required for the inhibition of fungal growth on thin-layer chromatography (TLC) plates being $5 \mu \mathrm{g}$. Interestingly, farinomalein $\mathrm{C}$ showed a ten-fold increased potency, inhibiting the fungal growth at $0.5 \mu \mathrm{g}$. Farinomalein $\mathrm{E}$ and $(R)-/(S)-/$ racemic farinomaleins D all showed a lower activity ( $20 \mu \mathrm{g})$, thus confirming that the stereochemistry did not affect the antifungal activity (Table 1).

To depict preliminary structure-activity relationships for this class of compounds, the results were compared to those obtained testing a series of farinomalein A derivatives previously prepared by our group ${ }^{4}$ (compounds 21a-d, Figure 2).<smiles>[R]C(C(=O)O)N1C(=O)C=C(C(C)C)C1=O</smiles>

21a $\mathrm{R}=\mathrm{H}$

21b $\mathrm{R}=\mathrm{CH}\left(\mathrm{CH}_{3}\right)_{2}$

21c $\mathrm{R}=\mathrm{CH}_{2} \mathrm{CH}\left(\mathrm{CH}_{3}\right)_{2}$

21d $\mathrm{R}=\mathrm{CH}_{2} \mathrm{Ph}$

Figure 2. Structures of farinomalein A analogues.

The minimum amount of compounds 21a-d required for fungal growth inhibition was 6 to 10fold larger than for $\mathbf{1}(30-50 \mu \mathrm{g})$ (Table 1).

The results clearly indicate that the introduction of different chains $\alpha$ to the carboxylic group, or the esterification with polar moieties, was detrimental for activity. Conversely, a lipophilic chain as in farinomalein $\mathrm{C}$ led to an increase of activity, comparable with that of the reference compound prochloraz. These data confirm that farinomaleins can be considered promising candidates in the field of antifungal compounds.

Current efforts are directed towards the synthesis of new analogues. Notwithstanding the fact that the molecular mechanism of action of the reported compounds remains to be defined, 
structure-activity information inferred from our study could provide a basis for rational design of new structurally simple antifungal agents and the starting point for their optimization.

Table 1. Antifungal activity of farinomaleins.

\begin{tabular}{cc}
\hline Compound & $\begin{array}{c}\text { Antifungal activity }(\mu \mathrm{g})^{\mathrm{a}} \\
\end{array}$ \\
\hline $\mathbf{1}$ & C. cladosporioides \\
$\mathbf{2}$ & 5 \\
$\mathbf{3}$ & 0.5 \\
$\mathbf{4}$ & 20 \\
$\mathbf{2 1 a}$ & 20 \\
$\mathbf{2 1 b}$ & 50 \\
$\mathbf{2 1 c}$ & 50 \\
21d & 30 \\
prochloraz & 50 \\
\hline a Minimum amount required for the inhibition of fungal \\
growth on thin-layer chromatography plates (TLC).
\end{tabular}

\section{References and Notes}

1. Putri, S. P.; Kinoshita, H.; Ihara, F.; Igarashi, Y.; Nihira, T. J. Nat. Prod. 2009, 72, 1544-1546.

2. El Amrani, M.; Debbab, A.; Aly, A. H.; Wray, V.; Dobretsov, S.; Muller, W. E. G.; Lin, W.; Lai, D.; Proksh, P. Tetrahedron Lett. 2012, 53, 6721-6724.

3. Miles, W.; Yan, M. Tetrahedron Lett. 2010, 51, 1710-1712.

4. Aiwale, S. A.; Dallavalle, S.; Sardi, P. Synth. Comm. 2012, 43, 1455-1459.

5. Preparation of farinomalein $C$. To a stirred solution of farinomalein A $(0.1 \mathrm{~g}, 0.47 \mathrm{mmol})$ in $\mathrm{DCM}(5 \mathrm{~mL})$ DMAP $(0.86 \mathrm{~g}, 0.70 \mathrm{mmol})$ was added and the mixture was stirred at room temperature under nitrogen for $10 \mathrm{~min}$. After addition of DCC $(0.146 \mathrm{~g}, 0.70 \mathrm{mmol})$ stirring was continued for further $30 \mathrm{~min}$ at room temperature, then 1-butanol $(0.053 \mathrm{~g}, 0.70 \mathrm{mmol})$ was added at $10^{\circ} \mathrm{C}$. The reaction mixture was stirred at room temperature overnight, then it was filtered through cotton and purified by column chromatography (ethyl acetate/hexane 2:8) to give farinomalein $\mathbf{C}(0.117 \mathrm{~g}, 92 \%)$. $\mathrm{R}_{f}=0.6$ (ethyl acetate/hexane 50:50). The spectroscopic data of the compound matched with those reported in the literature. ${ }^{2}$

6. Preparation of 3-(3-Isopropyl-2,5-dioxo-2,5-dihydro-pyrrol-1-yl)-propionic acid 2,2-dimethyl[1,3]dioxolan-4-ylmethyl ester (10). To a stirred solution of farinomalein A (0.2 g, $0.94 \mathrm{mmol})$ in DCM (10 $\mathrm{mL})$, DCC (0.292 g, $1.4 \mathrm{mmol})$, DMAP $(0.172 \mathrm{~g}, 1.5 \mathrm{mmol})$ and $(S)$-isopropylideneglycerol $9(0.187 \mathrm{~g}, 1.5$ mmol) were added at $0^{\circ} \mathrm{C}$. The resulting mixture was stirred at room temperature overnight under nitrogen, then it was filtered through cotton and purified by column chromatography (ethyl acetate/hexane 2:8) to give the title compound $(0.236 \mathrm{~g}, 77 \%)$. $\mathrm{R}_{f}=0.4$ (Ethyl acetate/hexane $\left.3: 7\right)$. [a] $]_{\mathrm{D}}{ }^{25}+1.3(\mathrm{c} 1.0, \mathrm{MeOH}) .{ }^{1} \mathrm{H}$ NMR $\left(300 \mathrm{MHz} \mathrm{CDCl}_{3}\right) \delta 6.22(1 \mathrm{H}, \mathrm{s}) ; 4.30(1 \mathrm{H}, \mathrm{m}) ; 4.19-4.02(3 \mathrm{H}, \mathrm{m}) ; 3.80(2 \mathrm{H}, \mathrm{t}, \mathrm{J}=7.3 \mathrm{~Hz}) ; 3.73$ $(1 \mathrm{H}, \mathrm{m}) ; 2.82(1 \mathrm{H}, \mathrm{m}) ; 2.66(2 \mathrm{H}, \mathrm{t}, \mathrm{J}=7.3 \mathrm{~Hz}) ; 1.42(3 \mathrm{H}, \mathrm{s}) ; 1.35(3 \mathrm{H}, \mathrm{s}) ; 1.20(6 \mathrm{H}, \mathrm{d}, \mathrm{J}=6.7 \mathrm{~Hz}) .{ }^{13} \mathrm{C}$ 
NMR (300 MHz, $\left.\mathrm{CDCl}_{3}\right) \delta \square 170.4,170.2,170.0,155.5,124.2,109.4,73.0,65.9,64.7,33.1,32.5,26.3$, $25.4,24.9,20.4(\times 2)$.

7. Mori, K. Tetrahedron 2012, 68, 8441-8449.

8. Preparation of (R)-Farinomalein D.(3) A solution of compound $\mathbf{1 0}(0.158 \mathrm{~g})$ in $\mathrm{AcOH} / \mathrm{H}_{2} \mathrm{O}(4: 1, \mathrm{v} / \mathrm{v} ; 4.66$ $\mathrm{mL}$ ) was stirred at $50^{\circ} \mathrm{C}$ (bath temperature) for $3 \mathrm{~h}$. The heating bath was removed, and saturated aqueous $\mathrm{NaHCO}_{3}(10 \mathrm{~mL})$ was added. The mixture was extracted with ethyl acetate $(3 \times 20 \mathrm{~mL})$. The combined organic extracts were washed with brine and dried with anhydrous sodium sulfate. The solvent was removed under reduced pressure and the residue was purified by flash chromatography on silica gel (Ethyl acetate) to obtain the title compound $(70 \%) . \mathrm{R}_{f}=0.35$ (Ethyl acetate/hexane 50:50). [a] ${ }_{\mathrm{D}}^{25}-7.2$ (c 1.0, $\mathrm{MeOH})$. The spectroscopic data of the compound matched with those reported in the literature. ${ }^{2}$

9. Nogawa, M.; Sugawara, S.; Iizuka, R.; Shimojo, M.; Ohta, H.; Hatanaka, M.; Matsumoto, K. Tetrahedron 2006, 62, 12071-12083.

10. Hitchcock, S. R.; Perron, F.; Martin, V. A.; Albizati, K. F. Synthesis 1990, 1059-1061.

11. White,. J. D.; Carter, J. P.; Kezar, H. S. J. Org. Chem. 1982, 47, 929-932.

12. Keller-Schierlein, W.; Widmer, J.; Maurer, B. Helv. Chim. Acta 1972, 55, 198-205.

13. Farinomalein E. To a stirred solution of farinomalein A ( $0.2 \mathrm{~g}, 0.94 \mathrm{mmol})$ in DCM (3 mL) DMAP ( 0.115 $\mathrm{g}, 0.94 \mathrm{mmol}$ ) was added and the solution was stirred at room temperature under nitrogen for $10 \mathrm{~min}$. After addition of EDCI. $\mathrm{HCl}(0.181 \mathrm{~g}, 0.94 \mathrm{mmol})$, the solution was stirred at room temperature for further 30 min., then $20(0.123 \mathrm{~g}, 0.94 \mathrm{mmol})$ dissolved in $2 \mathrm{~mL} \mathrm{DCM}$ was added at $10^{\circ} \mathrm{C}$. The reaction mixture was stirred at room temperature overnight. Purification by column chromatography (ethyl acetate/hexane 3:7) gave farinomalein E $(0.132 \mathrm{~g}, 42 \%) . \mathrm{R}_{f}=0.5$ (ethyl acetate/hexane 1:1). The spectroscopic data of the compound matched with those reported in the literature. ${ }^{2}$

14. Danelutte, A. P.; Lago, J. H. G.; Young, M. C. M.; Kato, M. J. Phytochemistry 2003, 64, 555-559.

15. Homans, A. L.; Fuchs, A. J. Chromatogr. 1970, 51, 327-329. 